\title{
Bioethics criteria in Dentistry research of humans
}

\author{
Critérios bioéticos em pesquisas em seres humanos \\ em Odontologia
}

\author{
Marta Artemísia Abel MAPENGO ${ }^{1}$ iD 0000-0003-4556-1859 \\ Sílvia Helena de Carvalho SALES-PERES ${ }^{1}$ iD 0000-0003-3811-7899 \\ Arsênio SALES-PERES ${ }^{1}$ iD 0000-0002-5110-1552
}

\section{ABSTRACT}

Objective: This study aimed to identify and relate the work that adopted bioethical principles applied to research on humans in the area of dentistry published in scientific journals. Methods: The selection of work was done using the Virtual Health Library $(\mathrm{VHL})$, including the following databases: Literature Latino-American and Caribbean Health Sciences, Scientific Electronic Library Online and International Literature on Health Sciences. It was evaluated in the last ten years, researches using the descriptors: Bioethics, Research, Human, Dental, Autonomy, Beneficence, Non-maleficence, and Justice. Results: Two hundred and seventy eight studies found, however only 12 were selected by following the criteria adopted in this study. Conclusion: Among the four principles of bioethics addressed in this study, the principle of autonomy was the most discussed in literature, followed the principle of justice. Further studies should be conducted in order to carry the development of bioethics in research with human made in dentistry.

Indexing terms: Beneficence. Bioethics. Dentistry. Personal autonomy.

\section{RESUMO}

Objetivo: O estudo objetivou identificar e relacionar trabalhos que adotaram os princípios bioéticos aplicados às pesquisas em seres humanos na área de odontologia publicados em revistas científicas. Métodos: A seleção de trabalhos foi realizada por meio da Biblioteca Virtual em Saúde (BVS), incluindo as seguintes bases de dados: LILACS (Literatura Latino-Americana e do Caribe em Ciências da Saúde), SciELO (Scientific Electronic Library Online) e MEDLINE (Literatura Internacional em Ciências da Saúde). Foram verificados os últimos dez anos, com os descritores: Bioética, Pesquisa, Seres Humanos, Odontologia, Autonomia, Beneficência, Não Maleficência, Justiça. Resultados: Dentre os 278 trabalhos encontrados, apenas 12 foram seleccionados, por obedecerem aos critérios adotados no estudo. Conclusão: Dentre os quatro princípios da bioética abordados no presente estudo, o princípio da autonomia foi o mais abordado na literatura, seguido do princípio da justiça. Outros estudos devem ser conduzidos para que se acompanhe a evolução da Bioética em pesquisas com seres humanos realizadas em Odontologia.

Termos de indexação: Beneficência. Bioética. Odontologia. Autonomia pessoal.

\section{$\checkmark \nabla v$}

1 Universidade de São Paulo, Faculdade de Odontologia, Departamento de Odontopediatria, Ortodontia e Saúde Coletiva. Al. Octávio Pinheiro Brisolla, 9-75, 17012-901, Bauru, SP, Brasil. Correspondência para / Correspondence to: SHC SALES PERES. E-mail: <shcperes@usp.br>.

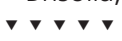

Mapengo MAA, Sales-Peres SHC, Sales-Peres A. Bioethics criteria in Dentistry research of humans. RGO, Rev Gaúch Odontol. 2018;66(4):289-295. http://dx.doi.org/10.1590/1981-863720180004000011295 


\section{INTRODUCTION}

The term bioethics arises in the 1970s, as a part of the Ethics, a term is related to the care of the progress of the biomedical sciences generating new considerations about the old problems [1-,2]. Bioethics is defined as an interdisciplinary study of all the conditions required by a responsible administration of human life, in view of the rapid evolution and complexity of biomedical knowledge and technologies [3]. This citation should not be limited to an individual perspective, without relating it to socail and communitary $[4,5]$.

Bioethics is based on four principles: autonomy, beneficence, non-maleficence and justice. Autonomy is the foundation that underlies consent, being an ability to think and act based on thought, and free and independent decision [6]. Beneficence is related to the critical analysis of risks, maximizationy the benefit as ideal for research with human beings. Non-maleficence is being represented in the researches in human being carried out when expressing knowledge from previous studies, whether with animals, in vitro and / or computer simulations, to avoid foreseeable damages [7]. The principle of justice requires equity in the distribution of goods and benefits in the area of health [8].

Bioethics must be pluralistic, multi-transdisciplinary and non-corporatist to be concerned with the scientificdomains of health, life or the environment, as well as withdaily problems [9].

Medicine has been exercised with authoritarianism for centuries. The oath of Hypocrites, in the fifth century BC, emphasizes beneficence and secrecy, but makes no mention of the patient's autonomy. In 1947, the Nuremberg Code was drafted by the Military Court of War in Nuremberg, where the consent of the participant in clinical research became indispensable. The main purpose of the code was to establish a set of rules to judge the atrocities committed by the Nazis in the name of science.

Other international documents emerged statements and guidelines on research involving human being: a Declaration of Human Rights (1948), a declaration of Helsinki (1964 and its later versions of 1975, 1983 and 1989), the International Covenant on Civil and Political Rights (UN, 1966, approved by the Brazilian National Congress in 1992), as International Guidelines for the Ethical Review of Epidemiological Studies [10,11].
The Helsinki Declaration of the World Medical Association of 1964, (revised several times, being an earlier issue at the 48th General Assembly of the Republic of South Africa) in 1996, states that research protocols in human being should be reviewed by the investigator's independent committee and that "reports of experimentation outside the principles of this Declaration should not be accepted for publication" [12].The National Health Council of Brazil approved guidelines and norms of research involving human beings, through Resolution No. 196/96, aimed at not prohibiting freedom of action, but ensuring the creation of ethical control mechanisms, creating conditions of effectiveness with flexibility, thus defining that all research involving human beings should be submitted to the appreciation of a Research Ethics Committee [13].

This study aimed to identify and relate papers that have adopted bioethical principles applied to human research in dentistry published in scientific journals.

\section{METHODS}

The collection of data on human research in dentistry in the scientific literature was carried out in the Virtual Health Library (VHL), through the following databases Latin American and Caribbean Literature in Health Sciences (LILACS), Scientific Electronic Library Online (SciELO) and International Literature in Health Sciences (MEDLINE) in the last ten years. In this study the following descriptors were used to select the articles: Bioethics, Research, Human Beings, Dentistry, Autonomy, Beneficence, Non-Maleficence, and Justice. These descriptors were used in the search in a combined and isolated way.

Regarding the criteria adopted for inclusion in this study, only articles published between 1998 and 2008 were used, whose themes were adequate to the one proposed in this study, clear ideas, objective and consistent with the title of the work, as well as the bioethical principles adopted in the area of dentistry. Articles that did not meet these criteria were not selected. Another exclusion criterion adopted was when the application of bioethics in non-dental areas, as well as when the bioethical principles were related to the professional profile.

\section{RESULTS}

After investigating the aforementioned databases, we reached a total of 30,142 papers in the scientific literature, distributed as follows 
Table 1. Total number of articles distributed per database according to descriptors.

\begin{tabular}{|c|c|c|c|}
\hline \multirow{2}{*}{ Descriptors } & \multicolumn{3}{|c|}{ Data base } \\
\hline & Lilacs & Medline & SCIELO \\
\hline Bioethics & 1711 & 3213 & 163 \\
\hline Bioethics and research & 271 & 888 & 42 \\
\hline Bioethics and Dentistry & 36 & 26 & 5 \\
\hline Beneficence and Bioethics and Dentistry & 6 & 1 & 2 \\
\hline Autonomy and Bioethics and Dentistry & 8 & 2 & 2 \\
\hline Justice and Bioethics and Dentistry & 2 & 3 & 0 \\
\hline Autonomy & 1438 & 9450 & 505 \\
\hline Beneficence & 192 & 751 & 174 \\
\hline Beneficence and Dentistry & 8 & 19 & 3 \\
\hline Non-maleficence and Dentistry & 3 & 0 & 0 \\
\hline Justice and Dentistry & 12 & 58 & 1 \\
\hline
\end{tabular}

Table 2. Distribution of articles, according to year, publication journal and bioethical principles.

\begin{tabular}{|c|c|c|c|}
\hline Article & Year of publication & Journal & Bioethical Principle \\
\hline The ethical problems in patient care at the dental teaching clinic & 2007 & Ciênc Saúde Coletiva & $A / J$ \\
\hline Oral health research with children & 2008 & Int J Paediatr Dent & A \\
\hline $\begin{array}{l}\text { Verification of the Bioethics Involvement in the Professional Activity of Two } \\
\text { Institutions in Bauru-São Paulo }\end{array}$ & 2005 & Braz J Oral Sci & A \\
\hline Beneficence and dental care for children with Down syndrome in the city of Recife & 1999 & Arq Odontol & $\mathrm{B} / \mathrm{J}$ \\
\hline Do you have a healthy smile? & 1999 & Med Health Care Philos & B \\
\hline Conflicts of interest: In whose interest? & 2004 & J Am Coll Dent & $A / B$ \\
\hline Where will the genome lead us? & 2001 & J Am Dent Assoc & No Ref. \\
\hline Ethical Aspects of Fluoride Product use in Brazil & 2006 & Ciênc. Saúde Coletiva & $\mathrm{B} / \mathrm{A} / \mathrm{N}$ \\
\hline
\end{tabular}

Note: A - autonomy; B - beneficence; J - justice; N - non-maleficence.

\section{DISCUSSION}

After the adoption of the inclusion and exclusion criteria as shown in Figure 1, of the 278 papers, 246 were excluded, since part of them was not related to the proposed topic and another part was unavailable or were books and theses. The triggering question for this research was based on the fulfillment of bioethical principles, autonomy, beneficence, non-maleficence, justice in researches with human beings. The excluded works related only to ethics during clinical practice, they referred to how to deal with patients with HIV in dental 


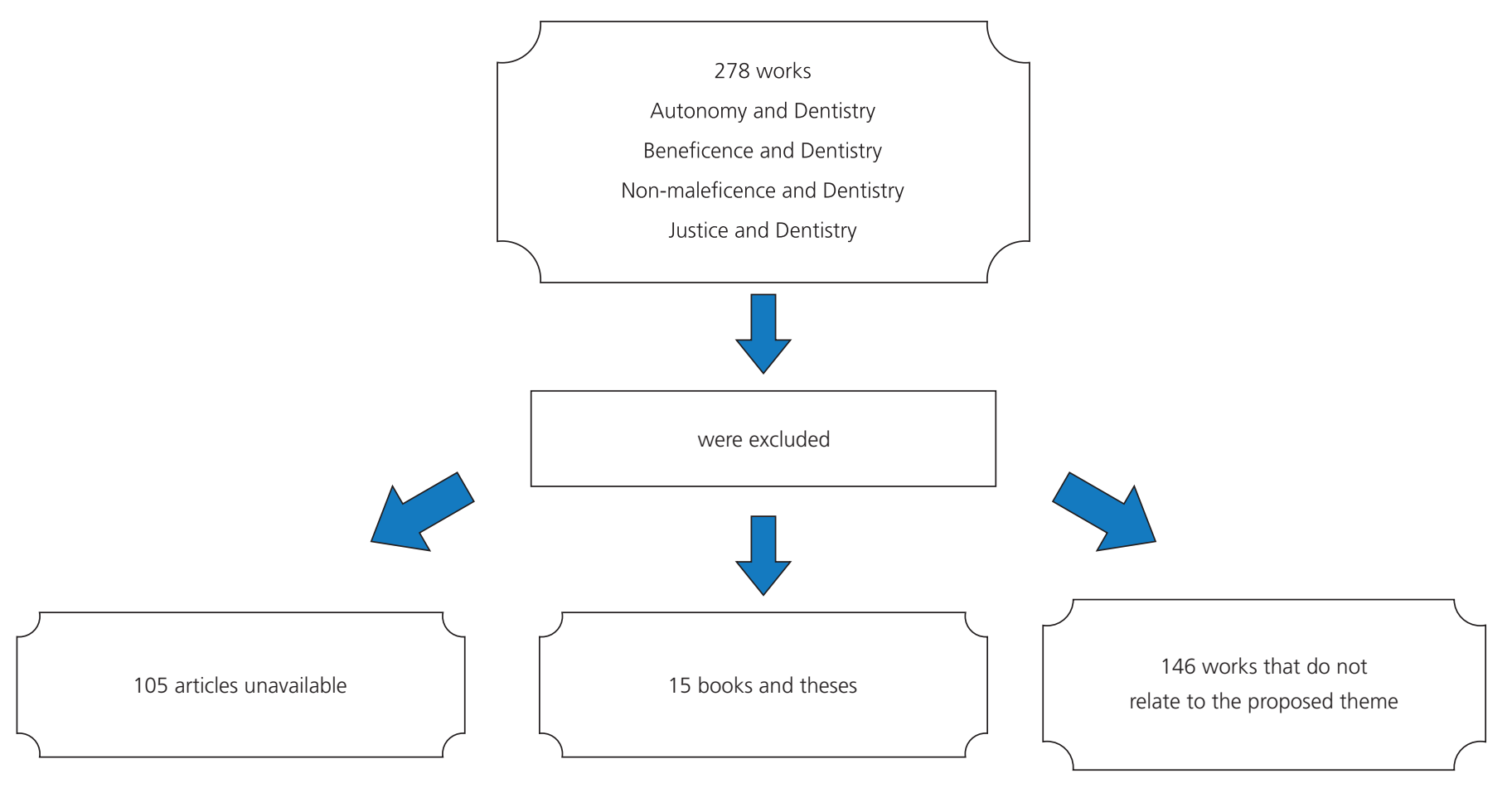

Figure 1. Schematic selection of articles included in the systematic review.

services. Therefore, the selected papers had some relation with the clinical activity.

Welie [14] analyzed aesthetic interventions performed by dentists and plastic surgeons classified as appropriate intervention. The aesthetic interventions, as well as the business strategies used to commercialize them, are often decided by the professionals involved. However, if these interventions do not qualify as appropriate intervention, their realization should not be considered ethical. The principles of bioethics should be safeguarded both in medical practice as well as in medical and dental aesthetic interventions. Unfortunately most interventions do not care about maintaining the patient's health, reconstituting the entirety of the patient, but rather are concerned with improving the physical appearance of the individual.

Zarzar \& Rosenblatt [15] evaluated children with Down syndrome, aged 3 to 10 years, of both genders, who underwent dental care. The methodology consisted of a comparative study of 30 children with Down syndrome (study group) and 30 children not suffering from the syndrome (control group) exposed to the same socioeconomic conditions, attended in 1997 and 1998, at the referral hospital special patients of the city of Recife, General Hospital of Areias. The principle of beneficence was evaluated through clinical exams, whose indicators used were the number of early extractions. They concluded that dental care for Down syndrome patients seems to fail on the bioethical principle of beneficence in relation to the control group if the curative aspects of a current care model are considered.

Sardenberg et al. [16], in its meta-analysis, found that in most Brazilian scientific journals there is little concern regarding the ethical aspects of human research, contained in the Instructions to Authors. On the other hand, the journals that make reference to the ethical aspects, the requirements are very variable. They also consider that journals should be more rigorous in ethical aspects, as they should standardize their ethical criteria.

Bugarin Júnior \& Garrafa [17] concluded in their work that professionals use biomaterials unaware of risks and adverse effects, distancing themselves from the principle of beneficence. The ethics of public responsibility is not observed by responsible public bodies and professional bodies. Informed consent is not yet incorporated into professional practice, and the professional-patient relationship in dentistry is excessively compartmentalized.

Aires et al. [18] revealed in their work that 38\% of the programs with concepts 5, 6 and 7 of CAPES maintain subjects of Bioethics, while $62 \%$ of programs with concepts 3 and 4 presented Bioethics contents. In 
this way, the results of this study represented an alert for the educators involved in teaching dental research. In addition, the results showed that education in bioethics is still incipient in the postgraduate programs in Dentistry in Brazil, although Resolution 196/96 of the National Health Council was published more than ten years ago. For this reason, it would be necessary to ensure an ethical pedagogy in the training of the young researcher.

The informed consent form in hospitals of federal districts was investigated by Maluf et al. [19], and it was demonstrated that the informed consent form is presented verbally to the patients at the beginning of the treatments, without prior clarification of the treatment to be performed. These authors demonstrated that dentists working in the public hospital network needed a deepening of the bioethical foundations to apply the informed consent form effectively during their integrated clinical research procedures.

Gonçalves \& Verdi [20] dealt with the problems in scheduling patient reservation, the privilege of attending teachers and staff acquaintances, the lack of information provided to patients about the performance of diagnostic and therapeutic procedures, distortions in the use of the informed consent term were analyzed in a recent study. The researchers emphasized the importance and responsibility of teachers in the academic training process, since it is fundamental to the ethical competence of future dentists.

A study conducted by Yeager [21] aimed at deciphering and interpreting the human genome and all other living organisms as a challenge for the 21st century. According to this author, dentistry will be deeply affected as the materials and methods used will be abandoned in favor of emerging technologies for prevention of diseases, tissue repair and diseases with resistance. However, the transition will be difficult from an ethical, legal and moral point of view. Therefore, the dental professional should prepare to face the challenge in addressing and solving these concerns.

The findings of Ozar [22] reinforced that conflicts of interest are unavoidable in dentistry, since there is commercial interest on the part of the researcher in testing his product, on the other hand, there is the interest of dentists in improving the quality of services provided to their patients. Although the public has its benefits in new technologies, it is necessary to know if the patient has an interest in being submitted to the new technology, since these can cause possible damages.
In the work of Moura et al. [23], in which they evaluated the role of the Ethics Committee, they verified that it is important to guarantee two moral requirements directly related to ethics in dealing with the research subject, which are the recognition of autonomy and protection those with reduced autonomy. This control can be done through the protocols that the patients will be submitted and must follow all criteria standardized by this entity. A minority of projects were returned due to the inadequacy of informed consent form; methodology applied; acquiescence of the entities involved; clarification on financial resources used in the research; incorrect fill of documents; definition of risk; execution chronogram.

A literature review conducted by Kalamatianos \& Narvai [24] aimed to identify ethical aspects related to the use of fluoride in public health related to the contradiction "prevention of caries versus the occurrence of mild fluorosis" caused the occurrence of ethical dilemmas about the use of these products among professionals involved decisions. Mild dental fluorosis, an undesirable effect, has raised concerns among specialists. Such a dilemma has been resolved by admitting that there would be justice in the use of fluoride and that its benefit would be greater than the harm, being this minimum. Some survey respondents recognized that violation of the ethical principle of autonomy could occur.

Marshman \& Hall [25] in their work were intended to provide a contemporary view of research approaches in children, considering the power that the adult researcher has in relation to the participating child. The use of language, research parameters, appropriate analysis, ethical factors such as the effects and risks of research, confidentiality, recruitment, funding, information to children and parents, consent, and disclosure should be taken into account. These authors consider that the oral health research of the child should actively involve them in research and rely on the collaboration of colleagues from other areas, as well as using appropriate methods in research addressing designs, vignettes and entertainment figures.

In the studies of Maluf et al. [19] it was verified that the individuals included in the research do not have autonomy in the treatment decision, to which they will be submitted. According to Closet [8] the principle of autonomy guides people to self-govern, recognizing the patient's control over life itself. For autonomy to be exercised there is a necessary ethical and normative condition that must be present, known as informed consent form. This 
consent is considered a process in which the patient confirms his availability to accept treatment after being properly informed about the procedures, their risks and benefits [26]. In the case of patients under 18 years of age, autonomy, that is, the right to consent or to refuse treatment, goes beyond the patient, reflecting on the parents/guardians or tutors [27]. In this way, parents and guardians deserve attention from the professional, since establishing an agreement with them is important so that the treatment of minors is successful [28].

In the investigation carried out by Gonçalves \& Verdi [20], the principles of beneficence and justice were not considered, since the assistance was intended especially for those known to teachers and employees, this mean that there was no impartiality in the distribution of benefits. All health services must be equitable and universal for all individuals, reducing the differences in access to benefits. Welie [14] in his work called into question the principle of beneficence, since the completeness of the individual was set aside in relation to aesthetics, showing that there is a conflict of interest. The same was observed in the works of Zarzar \& Rosenblatt [15] where the principle of justice was not respected, in which children with Down syndrome did not benefit from dental care.

We found only one article, Kalamatianos \& Narvai [24], which mentioned the occurrence of maleficence in dentistry, which was due to the implementation of fluoridation of the water supply, which may have caused mild fluorosis. In this study, what prevails is the costbenefit relationship, considering that fluoride acts in the prevention of large-scale caries. Therefore, the principles respected were those of beneficence and justice. However, the lack of autonomy on the part of the population has been identified, since they do not have a direct decision on this practice, of fluoridation in the public water supply.

Finally, the highlight the postulates of Yeager [21], which warns about contemporary clinical procedures offered by research subjects, which will involve new technologies, new subjects, because there is a risk of not observing bioethical principles. In all scientific research involving human beings, all principles must be taken into account since the beginning of the research.

If the research subject has any expenses to participate in the research, he should receive compensation, exclusive of expenses, resulting from him participation. On the other hand, if any damage occurs, he may receive a compensation for material coverage, in repair or immediate or late damage, caused to the research subject. All these efforts reinforce the adaptation of the main international declarations and guidelines on research with human beings to Brazilian legal and juridical reality [13].

\section{CONCLUSION}

The results allow us to conclude that among the bioethical principles in research on human beings in dentistry, those of autonomy, justice and beneficence were the conflictive and difficult to apply, while that of nonmaleficence was the most respected. Other studies should be conducted to accompany the evolution of Bioethics in research with human beings performed in Dentistry.

\section{Collaborators}

MAA MAPENGO, SHC SALES-PERES, and SALES-PERES participated in all stages of the article's elaboration.

\section{REFERENCES}

1. Hossne Ws, Vieira S. Experimentação com seres humanos: aspectos éticos. In: Segre M. Cohen C. Bioética. São Paulo: EDUSP, 1995; p.127-46.

2. Vásquez AS. Ética. Rio de Janeiro: Civilização brasileira; 2000.

3. Levine RJ. Ethics and regulation of clinical research. Baltimore: Urban \& Schwarzenberg; 1986.

4. Levine RJ. New International Ethical Guidelines for Research involving Human Subjects. Annals Int Med. 1993;119:339-41.

5. Sá AL. Ética profissional. São Paulo. Atlas; 1996.

6. Pessini L, Barchifontaine CP. Problemas atuais de bioética. 3a ed. São Paulo: Loyola; 1996.

7. Garrafa V ,Costa SI, Oselka G. Bioética e ciência: até onde avançar sem agredir. Iniciação à Bioética. Brasília: Conselho Federal de Medicina; 1998.

8. Clotet J. Por que bioética? Rev Bioética. 1993;1(1):13-17.

9. Araújo LZS. Aspectos éticos da pesquisa científica. Pesqui Odontol Bras. 2003;17:57-63.

10. Chramm FR, kottow M. Nuevos desafios para los Comités de Bioéica em investigación. Cuadernos Médico Sociales. 2000;1:1-2.

11. Botbol Bm. The shrinking of human rights: the controversial revision of the Helsinki Declaration. HIV Med. 2000;1:238-45.

12. World Medical Association. Declaration of Helsinki. JAMA. 1997;277:925-6.

13. Brasil. Diretrizes e Normas Regulamentadoras de Pesquisas Envolvendo Seres Humanos. Conselho Nacional de Saúde, Resolução n. 196/96: [citado 2018 Ago 25]. Disponível em: <http://www.ufrgs.br/bioetica/res19696.htm>. 
14. Welie JV. Do you have a healthy smile?; Med Health Care Philos. 1999;2(2):169-80.

15. Zarzar PMPA, Rosenblatt A. A beneficência e a atençäo odontológica às crianças portadoras da sindrome de Down na cidade de Recife. Arq Odontol. 1999;35(1/2):39-49.

16. Sardenberg T, Müller SS, Pereira HR, de Oliveira RA, Hossne HS. Análise dos aspectos éticos da pesquisa em seres humanos contidos nas Instruções aos Autores de 139 revistas científicas brasileiras. Rev Ass Med Brasil. 1999;45(4):295-302.

17. Bugarin Júnior JG, Garrafa V. Bioética e biossegurança: uso de biomateriais na prática odontológica. Rev Saúde Pública. 2007;41(2):223-8.

18. Aires CP, Hugo FN, Rosalen PL, Marcondes FK. Teaching of bioethics in dental graduate programs in Brazil. Braz Oral Res. 2006; 20(4):285-9. http://dx.doi.org/10.1590/S1806-83 242006000400001

19. Maluf F, Carvalho de GP, Diniz Júnior, JC, Bugarin Junior JP, Garrafa V. Consentimento livre e esclarecido em odontologia nos hospitais públicos do Distrito Federal. Ciênc Saúde Coletiva. 2007;12(6):1737-1746. http://dx.doi.org/10.1590/ S1413-81232007000600034

20. Gonçalves EV, Verdi MIM. Os problemas éticos no atendimento a pacientes na clínica odontológica de ensino. Ciênc Saúde Coletiva. 2007;12(3):755-764. http://dx.doi.org/10.1590/ S1413-81232007000300026

21. Yeager Arthur L. Where will the genome lead us? Dentistry in the 21st century. J Am Dent Assoc. 2001;132:801-807. https://doi.org/10.14219/jada.archive.2001.0280
22. Ozar D. Conflicts of interest: In whose interest? J Am Coll Dent. 2004;71(3):26-30.

23. Moura de PG, Sales Peres SHC, Pernambuco de RA, Sales Peres A. Verificação do envolvimento da bioética na atividade profissional de duas instituições em Bauru, São Paulo. Braz J Oral Sci. 2005;4(13).

24. Kalamatianos PA, Narvai PC. Aspectos éticos do uso de produtos fluorados no Brasil: uma visão dos formuladores de políticas públicas de saúde. Ciênc Saúde Coletiva. 2006;11(1):63-69. http://dx.doi.org/10.1590/S1413-81232006000100013

25. Marshman Z, Hall MJ. Oral health research with children. Int J Paediatr Dent. 2008; 18(4):235-42. https://doi.org/10.1111/j. 1365-263X.2008.00922.x

26. Emmerich A, Damaceno LM, Griffo JP, Santos RO. O consentimento livre e esclarecido na clínica odontológica e no campo da pesquisa odontológica. UFES Rev Odontol. 2000;2(1):20-27. https://doi.org/10.21722/rbps.v2i1.10676

27. Griffen AL, Schneiderman LJ. Ethical issues in managing the noncompliant child. Ped Dent. 1992;14(3):178-183.

28. Nobrega MSG. Importância dos conhecimentos psicológicos em odontopediatria. Rev Odontólogo Mod. 1987;22(3):10-8.

Received on: 5/5/2018 Final version resubmitted on: 27/6/2018 Approved on: 19/10/2018 